\title{
Comentario
}

\section{La lectura: una forma de la felicidad}

C n un memorabley memorioso texto $\mathrm{J}$ orge Luis B orges levanta el acta de su pasión y
sabiduría sobre la lectura diciendo:

M ontaigne apunta a que el concepto de lectura obligatoria es un concepto falso. D ice que si él encuentra un pasaje difícil en un libro, lo deja; porque ve en la lectura una forma de la felicidad (...) Yo he dedicado una parte de mi vida a las letras, y creo que una forma defelicidad es la lectura; otra forma de felicidad menor es la creación poética, o lo que llamamos creación, que es una mezcla de olvido y recuerdo de lo quehemos leído (...) Yo hetratado más de releer que de leer, creo que releer es más importante que leer, salvo que para releer se necesita haber leído.

El texto de donde fueron espigadas estas frases lleva el significativo título de El libro Como es sabido para B orges el libro fueel camino por donde deambuló toda su vida y fuela lectura queiluminó ese camino, aún por sobre la oscuridad de su ceguera. H ombreque sabíase destinado a la lectura y la escritura las vivió como una forma de la felicidad. El destino o vocación cuando es llevado hasta susúltimas consecuencias y sevive con plenitud de una u otra manera desemboca en la felicidad. En las palabras arriba convocadas, sin embargo, se da mayor rel evancia a la lectura que al acto creador y esen aquella dondeseal canza la plena felicidad, incluso, Borges reafirma esto al darle más importancia a la rel ectura, lo que es entendibleporque conduce a una profunda comunión con el autor leído. Es digno de meditar sobre la importancia de la relectura en un momento como el actual signado por lecturas apresuradas y superficiales 0 , como los especial istas dicen, por la lectura extensiva.

La rel ectura entraña un progresivo descanso hasta el corazón del texto, por lo que esuna lectura intensiva. Para el gran narrador sudamericano es en la relectura donde se conoce a los verdaderos amigos, en otras palabras, los autores fundamentales para la definición de nuestra vida, sobretodo aquellos cuya elevada estatura espiritual nos modela a la manera de un verdadero maestro. Las enseñanzas y bell ezas quesenos revelan con la rel ectura son precisamenteesa forma dela felicidad quenos refiere Borges. A unque a sus palabras cabría ha cer el señalamiento de que no es que la lectura se distinga de la creación poética o de cualquier otra puesto que, parafraseando a al gunos sociólogos, leer es en sí mismo un acto creador porqueesun consumo productivo, jamás una acción pasiva. D eahí su continuación natural con la creación propia de la escritura. Esto, empero, no ensombrece la hermosa visión de la lectura que articula el texto de Borges, por el contrario, la realza confirmando la 
indisoluble unidad que en su obra tienen lectura y escritura. Resulta a todas luces pertinente retornar en el presente a la visión borgeana de la lectura, cuando su práctica seha enrarecido hasta el extremo de ocultar su sencillez radicada en la felicidad.

Por su propia natural eza la felicidad no puede coludirse con la mercadotecnia masificadora. Lo quebrinda el consumo delas mercancías es placer, queal gunos con benignidad dirían que es un destello aunque degradado dela felicidad. El constante aumento del número delectores desdemediados del siglo XIX fueaparejado con el aumento dela producción bibliográfica. El exceso acabó por convertir en una mercancía más a los libros: El transitar de un libro a otro sin incurrir en relecturas, brinda el placer suficiente que soslaya la felicidad. Situación que se agudiza ahora con las nuevas tecnologías que reproducen vertiginosamentelos textos. Pero los reproducen fragmentados. El texto se convierte en esquirlas deinformación lo que redunda en que su lectura se convierta en un mero acto mecánico de desciframiento. A simismo, al desarticularsela continuidad argumentativa del texto el pensamiento paraliza su movimiento perdiéndose su capacidad crítica, sólo reproducel o quese le ofrece, no va más allá. Con el advenimiento de la sociedad dela información esta tendencia sefortalece, con lo quefinalmenteel sentido dela lectura sedifumina. La mercancía dela información que sólo exige una rudimentaria descodificación de los textos brinda un estupefaciente placer, del que sólo se puede escapar por ese túnel de la felicidad que nos señaló Borges lo que significa recuperar la unidad y la continuidad del texto, cuyo seguimiento a su vez depura la actitud crítica del pensamiento. Sobra decir que al retornar a la sencillez de la lectura como una forma de la felicidad, nos hace más dueños de nosotros mismos, lo que permite que pongamos a nuestro servicio las nuevas tecnologías que difunden los textos y no que nosotros nos pongamosa su servicio. La lectura entendida como una forma dela felicidad es, pues, un viaje que nos lleva al encuentro con nosotros mismos, y ello no obstante que se deba atravesar por las evanescencias del espacio virtual que crea la tecnología. 